\title{
Development of Biology Interactive Digital Flipbook on the Subject of Animal Growth and Development
}

\author{
Rifda Abadiyah 1), Jekti Prihatin 1), Siti Murdiyah 1). \\ ${ }^{1}$ Faculty of Teacher Training and Education, University of Jember \\ email: jekti.fkip@unej.ac.id
}

\begin{abstract}
Flipbook is organization of learning materials containing text, sound, animation, and video. This research aimed to produce a learning materials in the form of flipbook, especially on subject of animal's growth and development for science class grade XII. The flipbook produced should be valid, effective and practical for use in learning process. Flipbook is a 2 dimensional application that is reliable and lightweight. This study used 3 stages from 4 dimensional model which are define, design and develop. The implementation of the developed product was planned by 2 different tests, the first was limited testing and second was field trial. All tests implemented in 44 students of 12 IPA SMA Budi Utomo Sidoarjo. The results showed that 1) an average score of 81.43 gained from 3 different experts which falls into a very valid category, 2) field trial got an average score of 88.46 also falls into very valid category, 3) pre-test, post-test 1 and post-test 2 got normalized gain score at 0.78 which meant that the improvement of learning outcomes after using Flipbook was very high, 4) the effeciency based on the students' response was $97.72 \%$ which was interpreted in very good category. It can be concluded that the developed Flipbook was easy and feasible to use in learning.
\end{abstract}

Keywords: Flipbook, validity, effectiveness, practicality result, research and development

\section{INTRODUCTION}

As the increasing development of science and technology rapidly, it is necessary to have an innovation of education which is designed based on real needs in the field to achieve learning objectives. Therefore, special attention is needed from all parties, both from the government and society in an effort to improve the education system in Indonesia. One of the ways to improve the education system is the curriculum (Ningrum dan Sumartana, 2014). One of them is learning resource that is used in learning called teaching materials. Creating teaching materials is intended to facilitate teachers in implementing their learning. This is because the teaching materials determine the success of students' education in the learning process at school (Musani, 2015).

Biology learning is a process of activity to study about nature through scientific work to generate understanding of concepts, principles, scientific attitude which are useful for life (BSNP, 2007). In the implementation of learning, the problem can be minimized through the selection of teaching materials to improve students' learning interest. The low of students' learning behavior becomes the main problem in the learning process in high school. To overcome the problems, it needs a new breakthrough, especially in the use of teaching materials.

Development of teaching materials should pay attention to the demands of problem solving (Utomo, 2014). The problem is related to the subject lesson. Biology material in high school covers several subjects. One of them is growth and development. Basic competence on growth and developmental material consists of two indicators, namely growth in plants and growth in animals (Sembiring, 2009). The result of the interview and questionnaire filled by high school teachers showed that the concept of growth and development in biology only focused on plant.

Based on the questionnaire on high school students, it showed that $92.5 \%$ of students stated the teaching materials used in the biology learning process, especially on animals growth and development still use black and white student worksheet, 
using blur paper. This causes less interest and low level of students' understanding of the material.

This give rise to concern that it is necessary to provide high school students with proper learning source. In addition, high school actually already used IT-based learning. Therefore, researchers want to develop IT-based instructional materials in the form digital interactive flipbook which is expected to increase students' interest in learning and students' understanding on the concept of animal growth and development. The core concept to be developed as subject of content is the growth and development of silkworms (Bombyx mori L.).

The interactive digital flipbook is a lightweight yet powerfull 2-dimensional application. Flipbook developed in the form of a combination of text, animation, sound, video and so on (Diena dan Heri, 2010). Flipbook is widely used to build and provide interactive effects. Flipbook is also a perfect and complementary electronic book that has been existed to accommodate all interactive learning activities such as reading, writing and also quizzes and games (Warsito, 2008). The result of research that has been done in SMPN 10 Jember showed that the use of flipbook can improve students' creative thinking skill (Mulyadi, 2016). Previous research by researchers has shown that flipbook-based e-books can attract students' responses and improve students' learning outcomes (Gofur dan Rudi, 2015).

\section{RESEARCH METHOD}

This type of research is a combination research (Research and Development). This development research aimed to produce an interactive flipbook for high school students off XII on the subject of animal growth and development. The research used 4D models of development. However, the implementation of this research was limited to only 3 stages of define, design and develop.

Data obtained from this research included pre-validated product, score of pretest and posttest and student's responds. Data analyzed using qualitative and quantitative methods. Pre-validated product was validated by expert judgment, the result of pretest and post test were analyzed using gain score index. The implementation of product involved 44 students of class XII at SMA Budi Utomo Sidoarjo. Gain score index formula used was as follow

$$
\begin{aligned}
& \text { normalized gain }(\mathrm{g}) \\
& =\frac{\text { nilai posttest }- \text { nilai pretest }}{\text { nilai maksimal }- \text { nilai pretest }}
\end{aligned}
$$

The criteria for obtaining the gain index can be seen in Table 1.

Table 1. Criteria for Obtaining Index Gain

\begin{tabular}{cc}
\hline $\mathrm{N}$ (gain) & $\mathrm{N}$ \\
\hline $\mathrm{g}>0,70$ & High \\
\hline $0,30 \leq \mathrm{g} \leq 0,70$ & Middle \\
\hline $\mathrm{g}<0,30$ & Low \\
\hline
\end{tabular}

\section{RESULT AND DISCUSSION Result}

The results of this study were quantitative and qualitative data. After being analyzed descriptively, then interpreted according to the predetermined criteria. Based on Table 2, it can be seen that the average assessment of expert validation results on interactive digital flipbook is about 3.25 with a value of 81.43 which is interpreted in very valid category.

Table 2. Experimental Analysis of Flipbook Material Expert Validation

\begin{tabular}{lcl}
\hline Experts & $\begin{array}{l}\text { Average } \\
\text { score each } \\
\text { expert }\end{array}$ & $\begin{array}{l}\text { Level } \\
\text { validity }\end{array}$ \\
\hline Content & 3.30 & Very valid \\
\hline Development & 3.15 & Valid \\
\hline Media & 3.30 & Very valid \\
\hline Average & 3.25 & Very valid \\
\hline
\end{tabular}


Based on Table 3, it can be seen that the score of user validation get an average score of 3.53 with a value of 88.46 which is interpreted in very valid category.

\section{Table 3. Analysis Results of Flipbook} User Validation

\begin{tabular}{llll}
\hline $\begin{array}{l}\text { Valued } \\
\text { aspect }\end{array}$ & $\begin{array}{l}\text { Average } \\
\text { of each } \\
\text { Aspect }\end{array}$ & $\begin{array}{l}\text { Validity } \\
\text { Level }\end{array}$ & Value \\
\hline $\begin{array}{l}\text { Material } \\
\text { presentation }\end{array}$ & 3,35 & $\begin{array}{l}\text { Very } \\
\text { valid }\end{array}$ & 88,46 \\
\hline
\end{tabular}

From Table 4, it can be known the average assessment of legibility test was $90.73 \%$ and being interpreted in easy category with product decisions ready for use.

Table 4. Overall Analysis of Flipbook

Test Results

\begin{tabular}{cc}
\hline Response & Readibility level \\
\hline 1 & 96,66 \\
2 & 93,33 \\
3 & 76,66 \\
4 & 96,66 \\
5 & 90 \\
6 & 90 \\
7 & 93,33 \\
8 & 90 \\
9 & 90 \\
\hline Average & 90,73 \\
\hline Interpretation & Easy \\
& (product is ready to \\
& use) \\
\hline
\end{tabular}

Based on the results of pre-test and post-test 1 analyzed in Table 5 , it can be seen that there was an increase between pretest and post-test 1 score with an average increase of 32.5. The results are then analyzed using the Normalized gain formula to determine the improvement criteria. The average increase in value based on Normalized gain of 0,52 with criteria improvement of learning result in medium category.
Table 5. Pre-test and post-test 1 results

\begin{tabular}{|c|c|c|c|c|c|}
\hline $\begin{array}{l}\text { Research } \\
\text { subject }\end{array}$ & $\begin{array}{l}\text { pre- } \\
\text { test } \\
\text { avera } \\
\text { ge }\end{array}$ & $\begin{array}{l}\text { post- } \\
\text { test } 1 \\
\text { avera } \\
\text { ge }\end{array}$ & $\begin{array}{l}\text { Avera } \\
\text { ge } \\
\text { diff. }\end{array}$ & $\begin{array}{l}\text { Average } \\
\text { Normaliz } \\
\text { ed gain }\end{array}$ & Criteria \\
\hline $\begin{array}{l}44 \\
\text { students }\end{array}$ & $\begin{array}{l}38,40 \\
\pm 21,4 \\
3 \\
\end{array}$ & $\begin{array}{l}70 \pm 1 \\
5,43\end{array}$ & 32,5 & 0,52 & $\begin{array}{l}\text { Mediu } \\
\mathrm{m}\end{array}$ \\
\hline \multicolumn{6}{|c|}{ pre-tes score $t<$ post-test 1 score } \\
\hline
\end{tabular}

Table 6 shows the data of pre-test and post-test 2 results about 48.48 on average increase in value based on Normalized gain of 0.78 with the increasing student's achievement in criteria of high category.

Table 6. The result of Pretest and Posttest 2

\begin{tabular}{|c|c|c|c|c|c|}
\hline $\begin{array}{l}\text { Research } \\
\text { subject }\end{array}$ & $\begin{array}{l}\text { pre- } \\
\text { test } \\
\text { avera } \\
\text { ge }\end{array}$ & $\begin{array}{l}\text { post- } \\
\text { test } 2 \\
\text { avera } \\
\text { ge }\end{array}$ & $\begin{array}{l}\text { Avera } \\
\text { ge } \\
\text { differ } \\
\text { ence }\end{array}$ & $\begin{array}{l}\text { Average } \\
\text { Normaliz } \\
\text { ed gain }\end{array}$ & Criteria \\
\hline $\begin{array}{l}44 \\
\text { students }\end{array}$ & $\begin{array}{l}38,40 \\
\pm 21,4 \\
3\end{array}$ & $\begin{array}{l}86.88 \\
\pm 7,12\end{array}$ & 48,48 & 0,78 & High \\
\hline
\end{tabular}

Based on Table 5 and Table 6, it shows a significant increase between pretest and post-test 2 that is equal to 48.48 . The average increase in the value of learning set using a flipbook of 0.78 with the criteria of improved learning outcomes in the "high" category. Therefore, it can be concluded that students can understand the material and content of the flipbook, so as to improve students' learning outcomes.

\begin{tabular}{|llll}
$\begin{array}{l}\text { Table 7. Overall Analysis of Students' } \\
\text { Responds Results on Each } \\
\text { Statement }\end{array}$ \\
\hline No & Respond & $\begin{array}{l}\text { Average } \\
\text { Assess. } \\
(\%)\end{array}$ \\
& & Y & N \\
\hline 1 & $\begin{array}{l}\text { I can easiliy start to open } \\
\text { the front page of the } \\
\text { flipbook }\end{array}$ & 100 & 0 \\
\hline 2 & $\begin{array}{l}\text { I understand the usage of } \\
\text { the flipbook }\end{array}$ & 97,7 & 2,2 \\
\hline 3 & $\begin{array}{l}\text { I understand the learning } \\
\text { content materials in the } \\
\text { flipbook }\end{array}$ & 97,7 & 2,2 \\
\hline
\end{tabular}

Bioedukasi Vol. XVI. No.1 April 2018 


\begin{tabular}{|c|c|c|c|}
\hline 4 & $\begin{array}{l}\text { I can do the test of } \\
\text { learning result easily }\end{array}$ & $\begin{array}{l}95.4 \\
5\end{array}$ & $\begin{array}{l}4,4 \\
5\end{array}$ \\
\hline \multirow[t]{2}{*}{5} & I feel that the test is very & 95,4 & 4,4 \\
\hline & $\begin{array}{l}\text { easy to complete with the } \\
\text { help of the flipbook }\end{array}$ & 5 & 5 \\
\hline \multirow[t]{2}{*}{6} & I feel happy learning with & 97,7 & 2,2 \\
\hline & this flipbook. & 2 & 7 \\
\hline \multirow[t]{2}{*}{7} & I do not bored learn using & 97,7 & 2,2 \\
\hline & $\begin{array}{l}\text { this interactive flipbook } \\
\text { material }\end{array}$ & 2 & 7 \\
\hline 8 & $\begin{array}{l}\text { I can repeat the desired } \\
\text { section of the lesson }\end{array}$ & 100 & 0 \\
\hline \multirow[t]{2}{*}{9} & I am motivated to study & 88,6 & 11 , \\
\hline & $\begin{array}{l}\text { biology after learning } \\
\text { with this flipbook }\end{array}$ & 3 & 36 \\
\hline \multirow[t]{2}{*}{10} & I feel motivated to learn & 86,3 & 6,8 \\
\hline & $\begin{array}{l}\text { the growth and } \\
\text { development of animals } \\
\text { (metamorphosis of } \\
\text { silkworms) with the help } \\
\text { of flipbook software }\end{array}$ & 6 & 1 \\
\hline \multicolumn{2}{|c|}{ Total } & $\begin{array}{l}781 \\
78\end{array}$ & $\begin{array}{l}17, \\
98\end{array}$ \\
\hline \multirow{2}{*}{\multicolumn{2}{|c|}{ Overall average }} & 97.7 & 2,2 \\
\hline & & 2 & 5 \\
\hline \multicolumn{2}{|c|}{ Eligibility criteria } & & \\
\hline
\end{tabular}

Based on Table 7. it can be seen that the average assessment of students' responses to the flipbook is $97.72 \%$ and interpreted in very decent category with the decision of practical flipbook and ready to use.

\section{Discussion}

The development of teaching materials is carried out using 4-D model of development but the implementation of this research is limited to 3 stages only define, design, and develop. The teaching materials developed in the form of an interactive digital flipbook on the subject of animal's growth and development for XII grader at high school, which then tested the validity, effectiveness, and practicality. Define stage comprised of formulation of need analysis flipbook develop. Design stage which is the design stage produces draft 1, next to the develop stage with validation process by expert and user to field trial.

\section{a. Expert Valideation and Interactive Validation Flipbook Digital Book Users}

Flipbook developed in this study was validated by three experts namely subject of content expert, development expert, educational media expert and users who are 3 lecturers of FKIP biology education University Jember. During the validation process, a revision of the flipbook component is according to the suggestions and improvements provided by the validator.

Table 2. Shows that the average overall value of validation by experts on flipbook material on the subject of growth and development of animals for grade XII SMA obtained an average score of 3.25 with a value of 81.43 . Based on the validation result criteria, if the validation value ranges from $81.25<\mathrm{X} \leq 100$ it can be concluded that the flipbook developed has obtained very valid criteria. Draft 1 flipbook that has been declared valid still need to be perfected with minor improvements in some parts based on suggestions from validator. The revised details include: on the development aspect by fixing some components. The revised part is fixing the system from the flipbook, so the flipbook can be used in all types of notebook or personal computer and users are easy to operate.

The second part of the revision is the improvement of clarity or enlarging the image size and the improvement of the font size consistency. Some pictures are too small, so it improved by the change of font type and magnification of image size. The third part that should be revised is the color change in the background that has the contrast color with the writing, so that it's difficult to read. The suitability of colors can serve as guides and students' attention to the teaching materials (Arsyad, 2013). The last part to be revised is the competency test section. The number of competency tests is added again.

Fixed validation results on media aspects. Media users, especially in terms of 
design and graphics in learning, help students understand the difficult material substance, especially the difficult and complex ones (Leksono, 2008). Therefore, on the media aspect revision it is done in some parts, among them the first part is the content of the excess book which is less appropriate.

Second part, it is lack of consistency in the picture. In the flipbook there is some description on the image using the size of font size which is less consistent. So researchers need to make improvements to the description of the image to be consistent. Good teaching materials should take into account of the six elements at the time of designing, namely: consistency, use the consistency of formats from page to page, consistency in spacing, spacing and font type. So in the design of teaching materials, it needs to consider the consistency in everything. The third section, the concept map needs to be improved. There is a connecting arrow on the missing concept map, so there needs to be an improvement on the missing map part of the concept. The fourth part is the video in the flipbook which has no description. Therefore it is required to provide information in each section of the video displayed. The fifth part is the part giving additional number of competency test questions. The next improvement is the material aspect. Improvement on the cover is to add "PLUS" to clarify that silkworms are a perfect example of metamorphosis, and improve the writing in the cut content table beyond the layout limit.

The draft 1 that has been validated by an expert and revised produced draft 2 . The teachers of the classroom of the field of study take part in the process of assessment of teaching materials. Therefore, the draft 2 expert validation results are then continued in the validation stage by the teacher of the field of study as a user validator (BNSP, 2013).

Table 3 shows that the overall assessment by the user validator of the flipbook material obtained an average score of 3.53 with 88.46. According to the user validator, the overall flipbook is good, but it is better if it uses colors and songs that suit the students, so as to make the learning interesting and easy to read images and easy to read material.

Draft 2 that has been validated by the user was preceded to a limited trial stage on students of XII class SMA Budi Utomo Sidoarjo as respondents. A limited trial was conducted to determine the level of flipbook readability. This legibility test is the first phase of the flipbook teaching material tested directly to the students. Based on observations in the field, it is known that students are very enthusiastic when they were firstly receiving and studying the flipbook. It is seen when students get a chance to read the material in the flipbook. They use maximum time to learn the entire contents of the flipbook. After studying the contents of the flipbook, students are then directed to fill out the readability literature for flipbook assessments. Table 4. It shows that the average assessment of legibility test on the flipbook is $90.73 \%$ that interpreted in easyto-understand criteria with product decisions appropriate and ready to use.

The results of validation and legibility test indicate that the second draft of flipbook (draft 2) is clear, the content and appearance is interesting, and the content is easily understood by the students so it can be used without revision and then continued in the field trial phase.

\section{b. Flipbook Effectiveness}

Field trials were conducted by involving a class of 44 students majoring in science at SMA Budi Utomo Sidoarjo. One of the objectives of this field trial is to determine the effectiveness of the flipbook developed by analyzing learning outcomes.

The learning process is conducted for 2 meetings. Based on the results of pre-test analysis until post-test 2 , it showed a significant increase in value between pretest and post-test 2 that is equal to 48.48 . The average increase in value is based on 
Normalized gain of 0.78 so it can be stated that the developed flipbook is interpreted in high category.

The improvement of students 'learning outcome in field trials is influenced by interest in students' learning and enthusiasm, as well as the use of teaching materials during the lesson. Students' learning achievement is influenced by two main factors, namely: 1) factors from the students' inside, covering their ability, learning motivation, interest and attention, attitudes and study habits, perseverance, socio-economic, physical and psychological factors; 2) factors that come from outside the student's self or environmental factors, especially the quality in learning. In addition, the use of flipbook teaching materials during the learning process also affects students' interest and enthusiasm in learning (Sudjana, 1990).

The format of teaching materials in flipbook by displaying videos, pictures and sounds inducing interest in reading, this in turn will affect the level of understanding and learning outcome (Retnosari, 2016). Based on the results of experiments on the effectiveness of interactive flipbook, it can be concluded that students can understand the material and the content of flipbook, so as to improve students' learning outcome and test results flipbook effectiveness can be interpreted in the effective to be use in the learning process.

\section{c. Flipbook Practicality}

Flipbook practicality level can be known through the results of students' response analysis after being taught using flipbook. The result of students' response analysis indicated that the students were interested or motivated in learning. Based on Table 4.9, the average student who answered "Yes" reached $97.72 \%$, while the students who answered "No" reached $2.25 \%$. From the result, it can be said that the student's response to the interactive textbook material of the developed flipbook including the criteria is very feasible in the aspect of usability in the learning process in order to attract students to read the book and make them easier to understand the material of animal growth and development.

From the result of questionnaires to the students' response showed that the materials in developed flipbook are good and worthy. This is because the teaching materials are presented in accordance with the illustrations that can make students easier in understanding the material and attract students to read. Flipbook is practically used in the learning process, because the flipbook is a combination of text, animation, video, sound that can attract the interest of readers. So the flipbook has an advantage on the format compared to other teaching materials. Flipbook teaching material is easy to operate, flexsibel in all types of computers (reaching all types of digital), beautiful design on the layout and sound of songs in every video makes students motivated to read and learn (Warsito, 2008).

\section{CONCLUSION AND SUGGESTION Conclusion}

Based on the results of research that has been done, it can be concluded that 1) the test results validation of experts and users in developing interactive flipbook material on the subject of growth and development of animals for grade XII students with the value of expert validation about 3.25 with a value of 81.43 and user validation of 3.53 with a value of 88.46 which is interpreted in the category of very valid, so it is ready for use for field trial activities. 2) The experimental result of development of instructional material of interactive flipbook on the subject of growth and development of animal for grade XII high school students has a value based on Normalized gain of 0.78 with high criteria, so it is effective in improving students' learning outcomes. 3) The experimental results of the development of interactive flipbook materials on the subject of growth and development of animals for 
grade XII high school students have an average assessment of students' responses to the interactive flipbook of 97.72 and is interpreted in a very viable category by decision Flipbook interactive digital books are very practical to use in learning.

\section{Suggestion}

Based on the results of the research, the suggestion by the researchers as follows: 1) For high school teachers, this digital interactive flipbook that has been developed can be used as a guide book in Biology learning on the subject of growth and development of animals for XII IPA class. 2) For other researchers, this flipbook interactive digital book can be a reference and benchmark in developing teaching materials.

\section{REFERENCE}

Arsyad, A. 2013. Media Pembelajaran. Jakarta: PT. Grafindo Persada.

Badan Standar Nasional Pendidikan. 2013. Standar Penilaian Pendidikan: Buku Teks Pelajaran. [http: //bsnp indonesia. org/?page_id=345/pdf] diakses 13 Februari 2017.

Badan Standart Nasional Pendidikan. 2007. Kurikulum Tingkat Satuan Pendidikan. Jakarta: BSNP.

Diena, R dan Heri, S. 2010. Pengguna Media Flash Flipbook dalam Pembelajaran Teknologi Informasi dan Komunikasi untuk Meningkatkan Hasil Belajar Siswa. Jurnal Teknologi Informasi. Bandung: FMIPA UPI.

Ghofur, A., Rudi K. 2015. Pengembangan E-book Berbasis Flash Kvisoft Flipbook pada Materi Kinematika Gerak Lurus sebagai Sarana Belajar Siswa SMA Kelas X. Jurnal Inovasi Pendidikan Fisika (JIPF). Vol 4(2): 176-180.
Leksono, 2008. Upaya Peningkatan Aktivitas Belajar Siswa Melalui Penerapan Metode Penugasan Pada Materi Pokok Menulis di Kelas IV SD Negeri 050649 Simpang Pulau Rambung. Jurnal Saintech. Vol 6(2): 67-77.

Mulyadi, D U. 2016. Pengembangan Media Flash Flipbook untuk Meningkatkan Keterampilan Berfikir Kreatif Siswa dalam Pembelajaran IPA di SMP. Jember. Jurnal Pembelajaran Fisika. Vol 4(4): 296-301.

Musanni. 2015. Pengembangan Bahan Ajar Fisika SMA Berbasis Learning Cycle (LC)3E pada Materi Pokok Teori Kinetik Gas dan Termodinamika. Jurnal Penelitian Pendidikan IPA (JPPIPA), vol.1 (1): 102-122.

Ningrum dan Sumartana, 2014. Evaluasi Pendidikan. Surabaya: Usaha Nasional.

Retnosari, A. 2016. Penerapan Flipbook sebagai Bahan Ajar Pelajaran Biologi untuk Meningkatkan Minat Baca dan Hasil Belajar Siswa MtsN 1 Semarang pada Materi Interaksi Makhluk Hidup. Prosiding Seminar Nasional Sains dan Entrepreneurship III.

Sembiring, L. 2009. Biologi. Jakarta. Pusat kurikulum dan Perbukuan Kementrian Pendidikan Nasional.

Sudjana, N. 1990. Teori-teori Belajar Untuk Pengajaran. Bandung: Fakultas Ekonomi UI.

Utomo, A.P. 2014. Pengembangan Bahan Ajar IPA Berbasis Pebdekatan Sains Teknologi Mayarakat (STM) pada pokok Bahasan Limbah dan Penanganannya Kelas XI Sekolah Menengah Kejuruan (SMK). Skripsi. Program Studi Pendidikan Biologi, Fakultas Keguruan dan Ilmu 
Pendidikan, Universitas Jember, Jember.

Warsita, B. 2008. Teknologi Pembelajaran Landasan dan Aplikasinya. Jakarta: Rineka Cipta. 